\title{
УДК 338.240
}

\section{ІННОВАЦІї В СИСТЕМІ ЕКОНОМІЧНОЇ БЕЗПЕКИ ПІДПРИСМСТВ}

\author{
Захаров $O . I$. \\ кандидат економічних наук, професор, директор навчально-наукового інституту менеджменту безпеки, \\ Університет економіки та права «КРОК», \\ м. Киї, вул. Табірна, 30-32, 03113, Україна \\ тел.(044)-455-57-07, e-mail: zaharov@krok.edu.ua \\ ORCID: 0000-0002-4892-6414, DOI: https://doi.org/10.31732/2663-2209-2018-51-168-174
}

\section{THE INNOVATION IN THE SYSTEM OF ECONOMIC SECURITY OF ENTERPRISES}

\author{
O. Zakharov \\ $P h D$ in economics, professor, director of institute for security management, \\ «KROK» University, Kyiv, st. Tabirna, 30-32, 03113, Ukraine \\ tel.(044)-455-57-07, e-mail: zaharov@krok.edu.ua \\ ORCID: 0000-0002-4892-6414, DOI: https://doi.org/10.31732/2663-2209-2018-51-168-174
}

\begin{abstract}
Анотація. У статті розглянуто роль і значення інновачійної діяльності як найважливішого чинника удосконалення системи економічної безпеки підприсмства. Необхідність інноваційного розвитку систем економічної безпеки викликана тим, щя в умовах перманентної економічної кризи на діяльність підприємства чинять негативний вплив загрози, які постійно існують $i$ розвиваються у зовнішньому $i$ внутрішньому середовищі. У ичих умовах для забезпечення стійкої діяльність і розвитку підприємства необхідно постійну увагу приділяти розвитку його системи економічної безпеки. Для того, щяоб система економічної безпеки могла адекватно протидіяти не тільки тим загрозам, які існують в даний час, але й тим, щзо можуть виникнути в найближчій і віддаленій перспективі, необхідно ї̈ постійно модернізувати. Це можна здійснити лише за умови розробки та впровадження інновачій. У статті запропонована модель інновачійної діяльності в системі економічної безпеки підприємства. Розробка і впровадження інновацій в сфері економічної безпеки є складним процесом, успіх якого залежить від ряду об'єктивних і суб'єктивних факторів. Серед таких факторів слід назвати також позииію керівників підприємства щзодо інноваційного розвитку його системи економічної безпеки, а також наявних інтелектуальних, фінансових, матеріально-технічних та інших ресурсів без яких розробити та впровадити інновачії вкрай складно, а, в ряді випадків, практично неможливо. Для успішного здійснення інновачійної діяльності необхідно створити таку систему управління, яка здатна здійснювати моніторинг небезпечних для підприємства процесів, щуо відбуваються в економіці, своєчасно виявляти $i$ оцінювати існуючі $i$ прогнозувати появу нових загроз. А також аналізувати реальний стан системи економічної безпеки підприємства, виявляти ї̈ слабкі сторони і визначати ї̈ сегменти, які в першу чергу потребують модернізачії на основі впровадження інноващій.
\end{abstract}

Ключові слова: інновації, система економічної безпеки, підприємство, загрози, економічна криза, механізм управління, механізм взаємодії, недержавна система безпеки підприємництва в Украӥні.

Формул: 0, рис.: 3, табл.: 0, бібл.: 22

Anotation. In the article a role and value of innovative activity is considered as a major factor of improvement of the system of economic security of enterprise. The necessity of innovative development of the systems of economic security is caused that in the conditions of permanent economic crisis on activity of enterprise threats which constantly exist and develop in an external and internal environment render negative influence. In these terms for providing steady activity and development of enterprise permanent attention is needed to spare development of his system of economic security. In order that the system of economic security could adequately counteract not only to those threats which exist presently, but also that can arise up in the nearest and remote prospect it is necessary it constantly to modernize. It can be carried out only on condition of development and introduction of innovations. In the article the model of innovative activity is offered in the system of economic security of enterprise. Development and introduction of innovations in the field of economic security is a difficult process success of which depends on the row of objective and subjective factors. Including from position of leaders of enterprise in regard to innovative development of his system of economic security, and also present intellectual, financial, material and technical and other resources without which to develop and inculcate innovations extremely difficultly, and it is practically impossible in a number of cases. For successful realization of innovative activity it is necessary to create such control the system, which is able to carry out monitoring of unsafe for an enterprise processes which take a place in an economy, in good time to expose and estimate existing and to forecast appearance of new threats. And also to analyse the real state of the system of economic security of 
enterprise, expose its weak sides and determine its segments which above all things require modernization on the basis of introduction of innovations.

Key words: innovations, system of economic security, enterprise, threats, economic crisis, management mechanism, mechanism of co-operation, non-state system of safety of enterprise in Ukraine.

Formulas: 0, fig.: 3, tabl.: 0, bibl.: 22

Постановка проблеми. Забезпечення економічної безпеки вітчизняних підприємств в сучасних умовах залежить від їх здатності адекватно протидіяти існуючим та можливим загрозам зовнішнього і внутрішнього середовища. Для цього вони повинні мати ефективні системи економічної безпеки, що використовують сучасні технології, методи, методики i технічні засоби протидії всім існуючим і можливим загрозам для їх діяльності в умовах нестабільної економіки. Створення сучасних систем економічної безпеки неможливо без активного впровадження інновацій в їх структури, управління, технічні засоби і технології, що використовуються. 3 огляду на те, що розробка i впровадження інновацій в систему економічної безпеки є складним видом діяльності, що вимагає значних інтелектуальних, фінансових, матеріальнотехнічних та інших ресурсів, для його успішного здійснення необхідно використовувати всі власні ресурси підприємства. Для цього необхідно створити ефективний механізм управління i в повній мірі використовувати інтелектуальний потенціал підприємства.

Аналіз останніх досліджень $\boldsymbol{i}$ публікацій. Значний внесок у розвиток теорії та практики інноваційної діяльностівнесли відчизняні та зарубіжні вчені: В. А. Василенко [1], О. І. Захаров [2], В. В.Крутов [5], Р. А. Фатхутдинов [7], И. Шумпетер [8] Б. Твисс [9] та інші. В своїх працях автори розглядають питання управління впровадженням інновацій 3 метою забезпечення конкурентоздатності, розвітку та економічної безпеки сучасних підприємств.

Огляд наукових праць вітчизняних та зарубіжних вчених свідчить про те що питанням управління розробкою та впровадженням інновацій у системах економічної безпеки підприємств до наступного часу не приділялось достатньої уваги. Можливо, така ситуація зумовлена тим, що інноваційна діяльність в основному розглядалася як фактор вдосконалення техніки та технологій. Тому механізми управління розробкою та впровадженням інноваційних рішень при забезпеченні економічної безпеки підприємств потребують подальшого дослідження.

Формулювання цілей статmі. Метою статті $\epsilon$ розгляд питань організації інноваційної діяльності в системі економічної безпеки підприємства.

$\begin{array}{ccc}\text { Виклад } & \text { основного } & \text { матеріалу } \\ \text { дослідження. } & \text { Сучасна } & \text { економіка }\end{array}$
знаходиться в кризовому стані. На діяльність вітчизняних підприємств впливають різні несприятливі фактори зовнішнього середовища. У цих умовах найважливішим завданням власників i керівників підприємств є забезпечення їх економічної безпеки. В даний час в нашій країні вже накопичений певний позитивний досвід активної протидії існуючим загрозам для діяльності i економічної безпеки вітчизняних підприємств. Однак слід враховувати, що внаслідок безперервних змін, що відбуваються як в світовій, так і у вітчизняній економіці, постійно з'являються нові і трансформуються вже існуючі загрози для діяльності підприємств. Це добре видно на прикладі трансформації, що відбувається в такому небезпечному вигляді економічних злочинів як рейдерські захоплення чужої власності. Це виражається в тому, що в даний час відзначається різка активізація рейдерських атак в цій області економіки як сільське господарство. Про це наочно свідчить значна динаміка зростання рейдерських захоплень агропідприємств в період 2016 - 2017 років (Рис. 1).

У чому причина такої активності рейдерів саме щодо сільськогосподарських підприємств? 


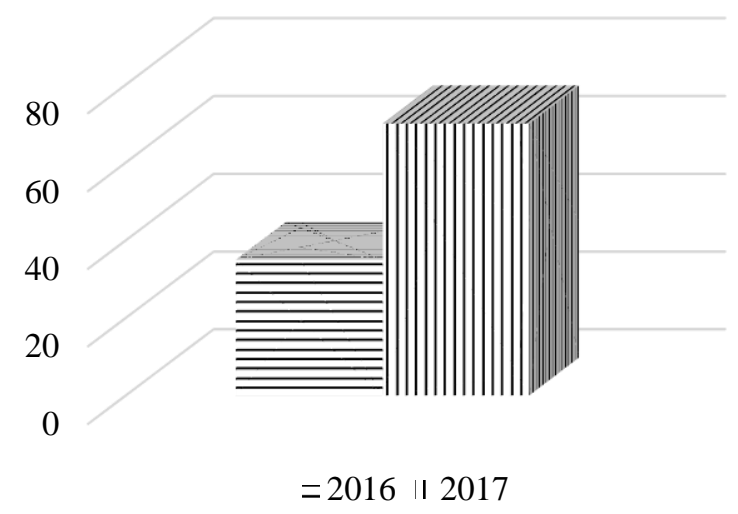

Рис. 1. Рейдерськи захоплення агропідприємств в $2016-2017$ роках

Джерело: розроблено автором на основі [6]

Причин тут декілька. Головна 3 них полягає в тому, що останнім часом в результаті впровадження інновацій, сільське господарство в Україні динамічно розвивається і стає прибутковим. За даними міністерства аграрної політики i продовольства виручка від експорту української аграрної продукції в 2017 році в порівнянні з 2016 роком збільшилася на $16.3 \%$ і склала 17.9 мільярда доларів (рис. 2). Іншою причиною стимулюючої дії рейдерів $\epsilon$ зростання вартості не тільки агропродукції, а й безпосередньо землі. А також не маловажной причиною $\epsilon$ можливе прийняття на законодавчому рівні рішення і про продажи землі в нашій країні. Все це стимулює дії рейдерів. Вони постійно вдосконалють свою тактику i технології захоплення чужої власності. Однак слід враховувати, рейдерство хоча i дуже серйозна, але, на жаль не єдина загроза безпеці бізнесу в Україні.

У цих умовах, для того щоб успішно протидіяти всім існуючим i можливим факторам загроз вітчизняняних підприємств, в якому б сегменті економіки вони не працювали, повинні звертати увагу на постійне вдосконалення своїх систем економічної безпеки. Вони повинні відповідати вимогам часу і бути здатними адекватно реагувати на всі зміни, що відбуваються як у вітчизняній, так i світовій економіці.

I завжди бути готовими адекватно реагувати на всі існуючі і знову виникаючі загрози для діяльності i економічної безпеки підприємств. Для цього, системи економічної безпеки повинні постійно вдосконалюватися на основі впровадження інновацій.

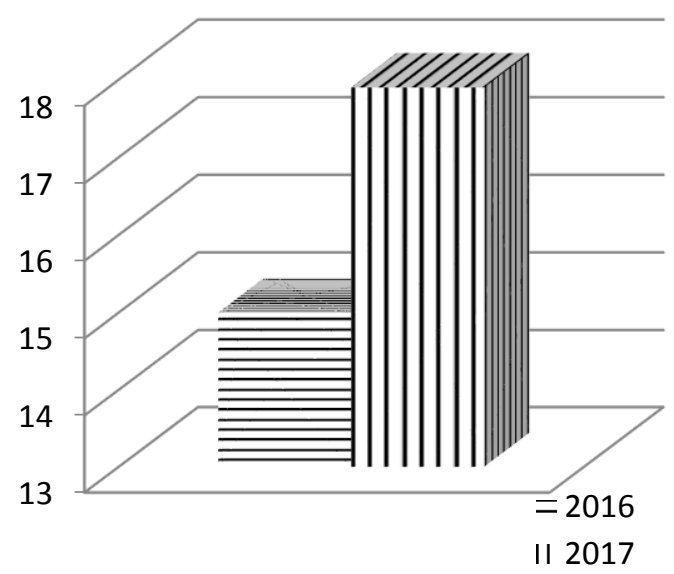

Рис. 2. Виручка від експорту української аграрної продукції 2016 - 2017 роках

Джерело: розроблено автором на основі [12]

Інноваційний розвиток системи економічної безпеки підприємств $\epsilon$ складним завданням, успішне вирішення якої залежить від багатьох факторів. Особливу роль тут відіграє позиція власників бізнесу i керівників підприємства щодо того, якою має бути система економічної безпеки. Вони повинні своєчасно і однозначно визначити роль і місце системи економічної безпеки на підприємстві, кількісні та якісні параметри iï персоналу, покладені на неї функції і завдання, а також механізми управління i взаємодії, структуру i інженерно-технічне оснащення. Важливу роль у створенні і забезпеченні ефективного функціонування системи економічної безпеки підприємства відіграють обсяги і своєчасність іiі фінансування. Адекватне фінансування дозволяє залучати необхідних висококваліфікованих фахівців у сфері безпеки та здійснювати якісне матеріально-технічне забезпечення діяльності 3 протидії всім існуючим i можливим загрозам економічної безпеки підприємства. 
3 огляду на постійне виявлення нових $\mathrm{i}$ зміни існуючих загроз у зовнішньому середовищі підприємства необхідно постійну увагу приділяти питанням модернізації його системи економічної безпеки. В даний час це можливо тільки за умови активного впровадження інновацій. Інноваційна діяльність в сфері забезпечення економічної безпеки сама по собі дуже складна. На думку автора [5] «... інновації у сфері економічної безпеки це розробка и впровадження нових форм организації системи безпеки, механізмів управління та взаємодії, технічних засобів та технологій, форм і методів протідії викликам, небезпеки, загрози та ризиків, застосування яких окремо в різніх видах комбінації підвіщує ефективність діяльності системи безпеки підприємства». Інноваційні рішення можуть стосуватися вдосконалення практично всіх компонентів системи економічної безпеки підприємства в тому числі:

- організаційної структури штатного підрозділу економічної безпеки підприємства;

- механізму управління діяльністю системи економічної безпеки підприємства;

- механізму взаємодії внутрішніх i зовнішніх суб'єктів системи економічної безпеки підприємства;

- технічних засобів відео спостереження та сигналізації;

- підвищення кваліфікації кадрів штатного підрозділу економічної безпеки;

- організації планування діяльності системи економічної безпеки;

- правого забезпечення діяльності щодо забезпечення економічної безпеки;

- технологій, методів і методик протидії різним видам загроз економічній безпеці підприємства.

Розробка і впровадження інновацій в системі економічної безпеки підприємства $\epsilon$ складним видом діяльності, позитивні результати якої залежать від ряду факторів.

По-перше, необхідно, щоб керівники підприємства були особисто зацікавлені в інноваційному розвитку системи економічної безпеки.

По-друге, на підприємстві повинні бути відповідні фінансові можливості для здійснення інноваційної діяльності.

По-третє, підприємство повинно мати відповідні інтелектуальні ресурси для розробки i впровадження інновацій в систему економічної безпеки.

По-четверте, необхідні адміністративні ресурси для організації процесу розробки і впровадження інновацій в діяльність системи економічної безпеки підприємства.

По-п'яте, значний вплив на розробку i впровадження інновацій надає науковотехнічний прогрес, в тому числі в сфері безпеки.

По-шосте, при здійсненні інноваційного розвитку системи економічної безпеки підприємства необхідно враховувати передовий досвід в цій сфері інших суб'єктів господарської діяльності, в тому числі і зарубіжних.

По-сьоме, успішна розробка та впроваджень інновацій в системі економічної безпеки в значній мірі залежить від правильного стимулювання фахівців, які задіяні для виконання цієї важливої і складної роботи.

Розглядаючи питання організації інноваційної діяльності в системі економічної безпеки підприємства слід враховувати, що «одним 3 найбільш цінних ресурсов підприємства $\epsilon$ его персонал. Від рівня інтелекту, кваліфікації, явних и неявних знань, мотівації та інших якостей співробітників підприємства залежать всі напрямки його діяльності у тому чіслі ... розробка інновацій ... » [2]. Ha кожному підприємстві $\epsilon$ висококваліфіковані фахівці, в тому числі в сфері IT технологій, безпеки, права, управління, економіки, фінансів, психології і так далі.

Розробка і впровадження інновацій в систему економічної безпеки є складним видом діяльності, що вимагає творчого підходу і прийняття нестандартних рішень 3 боку керівників підприємства. Модель інноваційної діяльності в системі 
економічної безпеки підприємства представлена на рисунку 3. Найважливішими пї компонентами $\epsilon$ система управління інноваціями та система економічної безпеки 3 усіма іiі складовими. За допомогою інформаційноаналітичної підсистеми системи управління інноваціями, керівники підприємства отримують інформацію про зовнішні i внутрішні загрози, стан i здатності системи економічної безпеки адекватно протидіяти виявленим загрозам, сучасних технологіях і технічних засобах забезпечення економічної безпеки i передовому досвіді в цьому виді діяльності в нашій країні i за кордоном. Дана інформація $\epsilon$ основою для прийняття рішення по модернізації існуючої системи економічної безпеки на основі розробки і впровадження інновацій.

Для того, щоб ефективно використовувати всі власні ресурси підприємства при здійсненні інноваційної діяльності необхідно створити творчі групи, в які повинні бути включені провідні фахівці необхідного профілю всіх структурних підрозділів підприємства. Слід також створити ефективний механізм взаємодії. На думку автора [3] «....механізм взаємодії в системі економічної безпеки підприємства - це сукупність внутрішніх і зовнішніх суб'єктів системи економічної безпеки, нормативно-правових баз i технічних засобів, що дозволяють планувати, здійснювати підготовку та проводити добре узгоджених за часом, місцем і змістом спільних дій...». Це дозволить найбільш раціонально використовувати при розробці i впровадженні інновацій у систему економічної безпеки підприємства інтелектуальні та інші ресурсі всіх структурних підрозділів підприємства.

Висновки. В умовах системної економічної кризи, успішна діяльність вітчизняних підприємств можлива тільки за умови ефективної протидії несприятливих факторів зовнішнього i внутрішнього середовища. Це можливо тільки при наявності у них сучасних систем економічної безпеки, які здатні адекватно протидіяти не тільки існуючим в даний час загрозам у сфері економіки, а також тим, що можуть виникнути в найближчій і віддаленій перспективі. Для побудови таких систем економічної безпеки необхідно використовувати всі досягнення науки i техніки, а також передовий досвід систем економічної безпеки найбільш успішних як вітчизняних, так і зарубіжних підприємств. В даний час побудова нових і модернізація існуючих систем економічної безпеки, 3 урахуванням реально існуючих i потенційних загроз, можливо тільки за умови активної інноваційної діяльності.

У сучасних умовах розробка i впровадження інновацій в систему економічної безпеки підприємства $\epsilon$ складним видом діяльності. Для успішного iii здійснення необхідно використовувати всі власні ресурси підприємства. Без розробки i впровадження інновацій в системі економічної безпеки, підвищити ефективність їх діяльності практично неможливо.

\section{Jimepamypa:}

1. Василенко В.А., Мельник И.Е. Стратегии и инновации в системе менеджмента : учебное пособие. Москва : МГИУ, 2001. 418 с.

2. Захаров О. І. Інноваційний менеджмент у сфері економічної безпеки. Зовнішня торгівля. Економічна безпека : наук. збірник. Київ, ТОВ «Дорадо - Друк» № 9. 2012. С.117-121.

3. Захаров О. І. Механізм взаємодії в системі управління комплексним забезпеченням економічної безпеки. Збірник наукових прачь Черкаського державного технологічного університету, Серія: Економічні науки, Випуск №43, Частина 1. / Черкаси: ЧДУТ, 2016.- С. 49-58

4. Зубок M. I. Інформаційна безпека в підприємницької діяльності: підручник. Київ :ТОВ «Гнозіс», 2015. $216 \mathrm{c}$.

5. Крутов В.В. Становлення та розвиток недержавної системи безпеки підприємництва в Україні : підручник. Київ : «Фенікс», 2008. 408 с.

6. Полный отжим: число рейдерских захватов агропредприятий в Украине за последний год увеличилось вдвое. УНIAH. URL : http:// economics.unian.net (дата звернення 02.09.2018).

7. Фатхутдинов Р. А. Инновационньїй менеджмент : науч. пособие. Санкт-Петербург : Питер, 2002. 400 с. 
ISSN (Print) 2307-6968, ISSN (Online) 2663-2209

Вчені записки Університету «КРОК» №3 (51), 2018

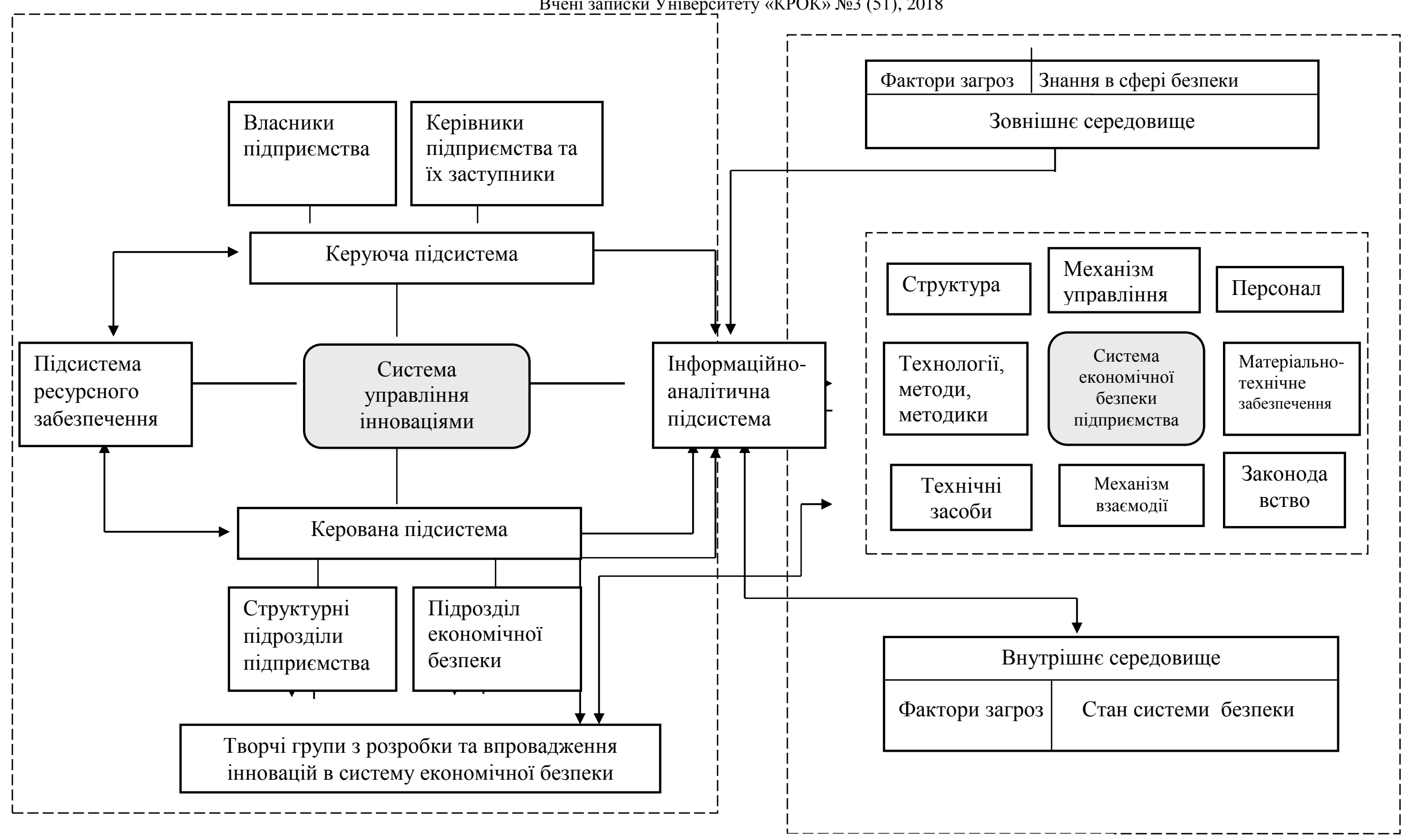

Рис. 3. Модель інноваційної діяльності в системі економічної безпеки підприємства 
8. Шумпетер И. Теория экономического развития. Москва : Пргресс, 1982.

9. Твисс Б. Управление научно-техническими нововведениями. Москва : Экономика, 1989.

10. Василенко В.А., Мельник И.Е. Стратегии и инновации в системе менеджмента : учебное пособие. Москва : МГИУ, 2001. 418 с.

11. Захаров О. І. Інноваційний менеджмент у сфері економічної безпеки. Зовнішня торгівля. Економічна безпека : наук. збірник. Київ, ТОВ «Дорадо - Друк» № 9. 2012. С.117-121.

12. Захаров О. І. Механізм взаємодії в системі управління комплексним забезпеченням економічної безпеки. Збірник наукових праць Черкаського державного технологічного університету, Серія: Економічні науки, Випуск №43, Частина 1. / Черкаси: ЧДУТ, 2016.- С. 49-58

13. Зубок M. I. Інформаційна безпека в підприємницької діяльності: підручник. Київ :ТОВ «Гнозіс», 2015. 216 с.

14. Крутов В.В. Становлення та розвиток недержавної системи безпеки підприємництва в Україні : підручник. Київ : «Фенікс», 2008. 408 с.

15. Полный отжим: число рейдерских захватов агропредприятий в Украине за последний год увеличилось вдвое. УНIAH. URL : http:// economics.unian.net (дата звернення 02.09.2018).

16. Фатхутдинов Р. А. Инновационньїй менеджмент : науч. пособие. Санкт-Петербург : Питер, 2002. 400 с.

17. Шумпетер И. Теория экономического развития. Москва : Пргресс, 1982.

18. Твисс Б. Управление научно-техническими нововведениями. Москва : Экономика, 1989.

19. Уткин Э.А. Инновационный менеджмент. Москва : Акалис, 1996.

20. Про інноваційну діяльність : Закон України. Сайт Верховної Ради України. URL : http:// rada.gov.ua/laws/show/40-15/ (дата звернення 02.09.2018)

21. АПК должен составлять 20-25\% украинской экономики. URL : http://milkua.info (дата звернення 02.09.2018).

22. Портал Безпека URL : http://bezpeka.com. (дата звернення 02.09.2018).

\section{Reference:}

1. $1 . \quad$ Vasylenko V.A., Melnyk Y.E. Stratehyy y ynnovatsyy $\mathrm{V}$ systeme menedzhmenta : uchebnoe posobye. Moskva : MHYU, 2001. 418 s.

2. Zakharov O. I. Innovatsiinyi menedzhment u sferi ekonomichnoi bezpeky. Zovnishnia torhivlia. Ekonomichna bezpeka : nauk. zbirnyk. Kyiv, TOV «Dorado - Druk» № 9. 2012. S.117-121.

3. Zakharov O. I. Mekhanizm vzaiemodii v systemi upravlinnia kompleksnym zabezpechenniam ekonomichnoi bezpeky. Zbirnyk naukovykh prats Cherkaskoho derzhavnoho tekhnolohichnoho universytetu, Seriia: Ekonomichni nauky, Vypusk №43, Chastyna 1. / Cherkasy: ChDUT, 2016.- S. 49-58
4. Zubok M. I. Informatsiina bezpeka v pidpryiemnytskoi diialnosti: pidruchnyk. Kyiv :TOV «Hnozis», 2015. $216 \mathrm{~s}$.

5. Krutov V.V. Stanovlennia ta rozvytok nederzhavnoi systemy bezpeky pidpryiemnytstva v Ukraini : pidruchnyk. Kyiv : «Feniks», 2008. 408 s

6. Polnыi otzhym: chyslo reiderskykh zakhvatov ahropredpryiatyi $\mathrm{v}$ Ukrayne za poslednyi hod uvelychylos vdvoe. UNIAN. URL : http:// economics.unian.net (data zvernennia 02.09.2018).

7. Fatkhutdynov R. A. Ynnovatsyonnii menedzhment : nauch. posobye. Sankt-Peterburh : Pyter, 2002. $400 \mathrm{~s}$.

8. Shumpeter Y. Teoryia эkonomycheskoho razvytyia. Moskva : Prhress, 1982.

9. Tvyss B. Upravlenye nauchnotekhnycheskymy novovvedenyiamy. Moskva : Эkonomyka, 1989.

10. Vasylenko V.A., Melnyk Y.E. Stratehyy y ynnovatsyy $\mathrm{V}$ systeme menedzhmenta : uchebnoe posobye. Moskva : MHYU, 2001. $418 \mathrm{~s}$.

11. Zakharov O. I. Innovatsiinyi menedzhment u sferi ekonomichnoi bezpeky. Zovnishnia torhivlia. Ekonomichna bezpeka : nauk. zbirnyk. Kyiv, TOV «Dorado - Druk» № 9. 2012. S.117-121.

12. Zakharov O. I. Mekhanizm vzaiemodii v systemi upravlinnia kompleksnym zabezpechenniam ekonomichnoi bezpeky. Zbirnyk naukovykh prats Cherkaskoho derzhavnoho tekhnolohichnoho universytetu, Seriia: Ekonomichni nauky, Vypusk №43, Chastyna 1. / Cherkasy: ChDUT, 2016.- S. 49-58

13. Zubok M. I. Informatsiina bezpeka $v$ pidpryiemnytskoi diialnosti: pidruchnyk. Kyiv :TOV «Hnozis», 2015. 216 s.

14. Krutov V.V. Stanovlennia ta rozvytok nederzhavnoi systemy bezpeky pidpryiemnytstva $\mathrm{v}$ Ukraini : pidruchnyk. Kyiv : «Feniks», 2008. 408 s.

15. Polnui otzhym: chyslo reiderskykh zakhvatov ahropredpryiatyi $\mathrm{v}$ Ukrayne za poslednyi hod uvelychylos vdvoe. UNIAN. URL : http:// economics.unian.net (data zvernennia 02.09.2018).

16. Fatkhutdynov R. A. Ynnovatsyonnii menedzhment : nauch. posobye. Sankt-Peterburh : Pyter, 2002. $400 \mathrm{~s}$.

17. Shumpeter Y. Teoryia эkonomycheskoho razvytyia. Moskva : Prhress, 1982.

18. Tvyss B. Upravlenye nauchnotekhnycheskymy novovvedenyiamy. Moskva : Эkonomyka, 1989.

19. Utkyn Э.A. Ynnovatsyonnыi menedzhment. Moskva : Akalys, 1996.

20. Pro innovatsiinu diialnist : Zakon Ukrainy. Sait Verkhovnoi Rady Ukrainy. URL : http:// rada.gov.ua/laws/show/40-15/ (data zvernennia 02.09.2018).

21. APK dolzhen sostavliat 20-25\% ukraynskoi эkonomyky. URL : http://milkua.info (data zvernennia 02.09.2018).

22. Portal Bezpeka URL : http://bezpeka.com. (data zvernennia 02.09.2018). 